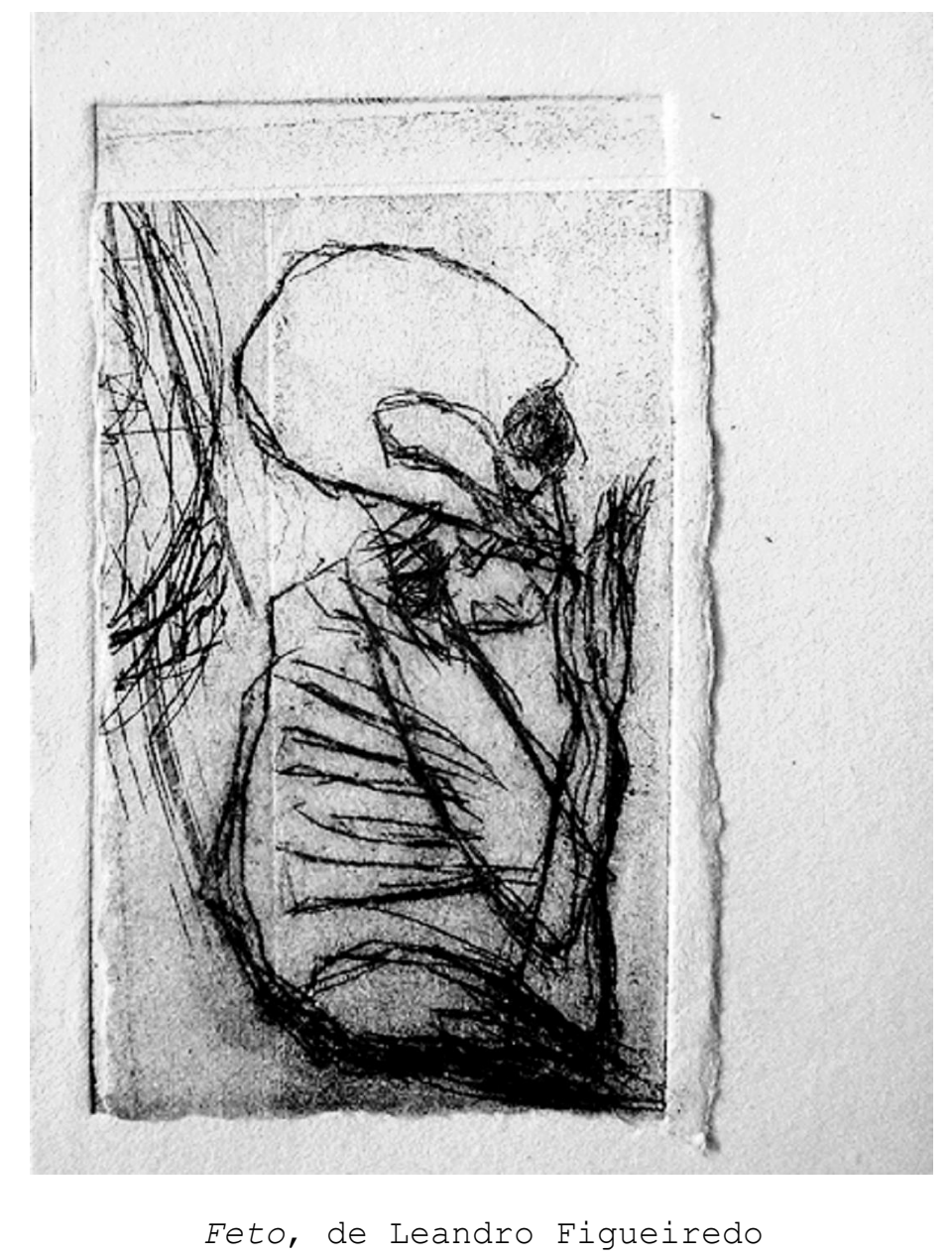

\title{
OS ANIMAIS PODEM SOFRER?
}

\section{Maria Antonieta Pereira}

Pós-doutora em Literatura Comparada. Professora aposentada FALE/UFMG. Coordenadora geral do Programa A tela e o texto.

Trata-se de uma guerra a propósito da piedade. Jacques Derrida

A partir de uma cena doméstica, em que observa sua própria nudez contemplada pelo olhar de um gato (ou gata?), Derrida volta a questionar uma longa tradição filosófico-religiosa ocidental que separa humanos de não-humanos com base em critérios que priorizam a capacidade de falar e raciocinar dos primeiros. Aliando-se a outra tradição(1), Derrida redireciona a discussão do problema com uma pergunta cuja resposta denuncia, mais uma vez, o alto grau de logo/antropocentrismo do Ocidente. 
Os animais podem sofrer? A resposta a essa questão, além de provocar desconforto devido à sua obviedade, também coloca em outras bases as complexas relações entre os seres vivos. Não se trata, nesse caso, de distinguir os humanos dos outros animais pela remissão a um logos capaz de estabelecer aquilo que se considera o próprio do homem. Trata-se de indicar a existência de outro poder, que denuncia justamente a completa falta de poder dos não-humanos frente aos humanos. Para Derrida,

poder sofrer não é mais um poder, é uma possibilidade sem poder, uma possibilidade do impossível. Aí reside, como a maneira mais radical de pensar a finitude que compartilhamos com os animais, a mortalidade que pertence à finitude propriamente dita da vida, à experiência da compaixão, à possibilidade de compartilhar a possibilidade desse não-poder, a possibilidade dessa impossibilidade, a angústia dessa vulnerabilidade e a vulnerabilidade dessa angústia.(2)

Os animais podem sofrer? A resposta afirmativa a essa pergunta e, mais que isso, o próprio fato de essa pergunta ser formulada, desvela o estado ainda embrionário da crítica ao antiquíssimo problema da exploração dos outros animais pelos homens. Segundo Derrida, essa luta desigual não viola apenas a vida dos animais, mas também corrompe o próprio sentimento de compaixão. Modificando o teor do que deve ser investigado, o pensador estimula outros questionamentos $e$, nessa medida, avança em uma discussão cuja complexidade desnuda as raízes logocêntricas do especismo. Criado pelo filósofo Peter Singer, nos anos 70, o vocábulo "especismo" é usado para indicar o preconceito da humanidade contra os chamados "animais irracionais"(3). No prefácio da primeira edição de Animal liberation, afirma Singer:

Este livro é sobre a tirania dos humanos sobre os animais nãohumanos. Essa tirania tem causado e ainda hoje está causando muita dor e sofrimento, os quais só podem ser comparados com o resultado de séculos de tirania dos brancos sobre os negros. A luta contra essa tirania é uma luta tão importante quanto quaisquer questões morais e sociais que têm sido debatidas nos últimos anos(4). [tradução minha]

No âmbito desse debate - cuja importância cresce à medida que as idéias de igualdade, direito e ética vão sendo reformuladas como uma reação às demandas do capitalismo neoliberal -, Singer desenvolve argumentos que fortalecem uma política voltada para a libertação animal. Sua proposta tem como base a idéia de senciência.

Para o filósofo, o conceito de "senciência" indica a condição de animais dotados de atividades mentais específicas, que lhes permitem desenvolver experiências sensíveis nas interações com os ambientes naturais e sociais. Considerando que essa 
sensibilidade implica a existência de níveis de consciência da dor e do sofrimento (ou do prazer e do bem-estar), Singer defende que os humanos têm o dever moral de não provocar dor ou sofrimento nos animais. Ao serem considerados como sujeitos com interesses próprios - e não como meros objetos para uso humano -, os outros animais provocam, no cenário filosófico do final do século 20, uma das formas mais radicais de combate ao logocentrismo.

Tal como Singer, Derrida investiga a história dessa tirania mostrando como as narrativas fundadoras do Ocidente, ao discorrerem sobre os animais(5), buscaram distingui-los dos homens por meio de uma deficiência básica - sua incapacidade de pensar/falar. Questionando as narrativas genesíacas, os mitos gregos, a filosofia cristã e o Iluminismo, ambos os autores divergem de um saber que sempre legitimou a crueldade, a dominação e a exploração sem limites dos animais por considerá-los irracionais e bestiais, privados de palavras e saberes. Raros filósofos ocidentais, dentre os quais se destacam Montaigne e Nietzsche, desenvolveram um pensamento divergente dessa trajetória - em que o uso dologos justificou e justifica uma ética humana preocupada apenas com a própria espécie. Para Derrida, o próprio do homem - aquilo que tão acirradamente 0 homem busca estabelecer como a diferença básica entre ele e o Animal - não passa de uma relação da humanidade consigo mesma, "antes de mais nada preocupada com seu próprio e ciumenta em relação a ele"(6).

Nessa perspectiva, o próprio do homem seria, portanto, o próprio homem. Dessa forma, as relações entre logocentrismo, antropocentrismo e especismo tornam-se bastante claras e, mais que isso, consequentes e necessárias. Combater esse sistema de pensamento, para Singer, significa abolir a escravidão de todos os animais, inclusive a dos humanos, já que tal empreendimento levaria à modificação dos valores fundados nas práticas de sujeitar, dominar, domar, adestrar, domesticar, devorar, violentar... Também para Derrida, é preciso desenvolver uma nova ética, que seja capaz de considerar humanos e não-humanos como sujeitos dignos de participarem de uma mesma comunidade moral.

Discutindo a cena do pecado original - em que, não por acaso, a mulher e a serpente, animais femininos, desconstroem uma ordem masculina - Derrida associa a nudez envergonhada dos pais primordiais à presença do logos. A visão crítica decorrente da descoberta do bem e do mal acarreta a consciência da própria nudez e a expulsão do paraíso. Doravante, em linguagem articulada e racional, a humanidade evitará ficar nua, ao contrário dos outros animais que nunca estarão nus justamente porque são nus. Se o próprio do animal é estar nu sem sabê-lo, para uma visão antropocêntrica, 
essa seria mais uma prova de que ele não sabe de si. A ausência de uma linguagem articulada - que fosse capaz de demonstrar a consciência de si - funciona como a garantia da inferioridade espiritual e cognitiva dos não-humanos, justificando sua escravização. Noutras palavras, os humanos não consideram que um animal não-humano possa se dirigir a eles, comunicar-se, perguntar e responder, fazer-se entender e reconhecer: o logocentrismo leva necessariamente ao especismo e às suas refinadas formas de brutalidade, sadismo, violência, indiferença e crueldade contra a vida.

Contudo, Derrida argumenta que Adão e Eva só recebem a missão de sujeitar os animais criados por Deus porque eles vêm depois desses animais, porque eles seguem esses animais numa temporalidade cronológica. E pergunta: Quem nasceu primeiro? Quem foi o primeiro ocupante da Terra e, portanto, o senhor? Quem continua sendo o déspota? Quem priva o outro do poder de manifestar sua experiência de linguagem, sua pseudomudez? Opondo-se à negativização do silêncio dos animais e à suposta tristeza advinda desse silêncio, Derrida questiona as posições de certos pensadores, seja quando associam esse mutismo à tristeza de terem sido privados da linguagem (Benjamin), seja quando mostram como o animal não tem acesso ao ser do ente (Heidegger).

Para Derrida, nos últimos 200 anos, as fronteiras entre os animais humanos e não-humanos estão se alterando de forma muito rápida e exacerbando um processo planejado, controlado e organizado de assujeitamento. Trata-se de um investimento maciço em saberes de vários campos da ciência voltados para criação e industrialização em larga escala, adestramento, experimentação genética, inseminação artificial, manipulação do genoma, produção e reprodução superestimulada por hormônios, cruzamentos genéticos e clonagem. Todo esse aparato de dominação equivale a um verdadeiro genocídio, a uma tortura organizada e legitimada, a uma violência justificada pelas necessidades de produção, criação, transporte e abate de nãohumanos, em favor dos humanos.

A desconstrução derridiana fustiga essa visão de mundo estreitamente antropocêntrica, mostrando a necessidade de se definir direitos para os animais e propondo o desenvolvimento de outros códigos éticos. Nesse cenário, novos valores vão irrompendo, na medida em que algumas palavras - como piedade podem ser ressignificadas para se dirigirem aos não-humanos.

Um poder de outra natureza - um não-poder, um poder sofrer, uma ausência de poder logocêntrico - questiona as certezas do "penso, logo sou" cartesiano. O animal que [logo] souprovoca a imersão do leitor em diferentes níveis de percepção e 
consciência, na medida em que lhe propõe o dever de piedade para com os outros animais.

\section{Notas}

[1]Derrida retoma a discussão ética iniciada por Jeremy Bentham que, em 1789, publicou An Introduction to the Principles of Morals and Legislation, obra na qual, pela primeira vez, a filosofia defende claramente os interesses dos animais. Reivindicando ética e coerência com os princípios da igualdade e da dignidade - que definem o tratamento a ser dado aos humanos - Bentham afirma que o regime republicano deveria estender tais princípios a todos os animais.

[2] DERRIDA, 2002. p. 55.

[3] O especismo constitui a discriminação de outras espécies por parte dos humanos, visando atender apenas aos interesses da própria espécie. Cf. SINGER, 2002 .

[4]This book is about the tyranny of human over nonhuman animals. This tyranny has caused and today is still causing an amount of pain and suffering that can only be compared with that which resulted from the centuries of tyranny by with humans over black humans. The struggle against this tyranny is a struggle as important as any of the moral and social issues that have been fought over in recent years. Cf. SINGER, 3.ed. 2002. p. $\mathrm{xx}$.

[5] Derrida denuncia o uso do termo no singular - o Animal - como categoria reveladora de uma oposição tão forte entre humanos e não-humanos que transforma os últimos em uma massa amorfa, isenta de singularidades. Como resultado disso, o Animal constitui-se como um ser - melhor seria dizer, como um vivente - somente na medida em que se torna um objeto para os humanos, suprindo suas necessidades. Como sua singularidade não é reconhecida, também lhe negam interesses próprios e, portanto, direitos.

[6] DERRIDA, 2002. p. 34 .

\section{Referências bibliográficas}

CARTA DA TERRA. Disponível em: www.mma.gov.br/estruturas/agenda21/arquivos/carta_terra.doc. Acesso em: $17 / 05 / 2009$.

DECLARAÇÃO UNIVERSAL DOS DIREITOS DOS ANIMAIS (UNESCO). Disponível em: http://www.apasfa.org/leis/declaracao.shtml. Acesso em: 17/05/2009.

DERRIDA, Jacques. O animal que logo sou (a seguir). Trad. Fábio Landa. São Paulo: Ed. UNESP, 2002 .

SETOR VERDE. Programa de Ensino, Pesquisa e Extensão A tela e o texto. Disponível em www.letras.ufmg.br/atelaeotexto. Acesso em: 17/05/2009.

SINGER, Peter. Animal Liberation. New York: HarperCollins Publishers Inc. 3. ed. 2002 . 